\title{
A cytoplasmic lectin produced by the fungus Arthrobotrys oligospora functions as a storage protein during saprophytic and parasitic growth
}

\author{
Stefan Rosén, ${ }^{1}+$ Klaas Sjollema, ${ }^{2}$ Marten Veenhuis ${ }^{2}$ and Anders Tunlid ${ }^{1}$
}

Author for correspondence: Anders Tunlid. Tel: +46 46 2223757. Fax: +46 462224158. e-mail : anders.tunlid@mbioekol.lu.se

1 Department of Microbial Ecology, Lund University, Ecology Building,

Solvegatan 37, S-223 62

Lund, Sweden

2 Laboratory of Electron Microscopy, University of Groningen, Biological Centre, Kerklaan 30 , 9751 NN Haren, The Netherlands

\begin{abstract}
It was recently shown that the nematode-infecting fungus Arthrobotrys oligospora contains a saline-soluble lectin (designated AOL) that is a member of a novel family of fungal lectins sharing similar primary sequences and binding specificities. During saprophytic growth in liquid cultures, levels of AOL and AOL mRNA were found to vary depending on the growth phase of the mycelium and the carbon/nitrogen (CNN) ratio of the medium. AOL was not detected in young mycelium. In older mycelium (stationary growth phase) grown in media with low C/N ratios (1 or 6), AOL comprised 5-20\% of the total amount of saline-soluble proteins present in the mycelium. Neither the lectin nor its transcript was detected in mycelia grown in medium with higher $\mathrm{C} / \mathrm{N}$ ratios ( $\geq 150)$. Under conditions of nitrogen starvation, AOL was preferentially degraded in relation to the total amount of saline-soluble proteins present in the mycelium. During the infection of nematodes, the level of AOL protein and AOL mRNA increased significantly once the nematodes had been penetrated and digested. Large amounts of AOL accumulated in the trophic hyphae growing inside the nematode as visualized by immunofluorescence microscopy. Later, AOL labelling was detected outside the digested nematodes, preferentially in strands of aggregated hyphae and in newly developed trap cells. Electron microscopy showed that AOL was localized to the cytoplasm and the nucleus of both vegetative mycelium and trap cells, and in the trophic hyphae growing inside the infected nematodes. These results indicate that $\mathrm{AOL}$ functions as a storage protein during both saprophytic and parasitic growth.
\end{abstract}

Keywords: lectin, immunolocalization, storage protein, nematophagous fungus

\section{INTRODUCTION}

A number of fungi produce high levels of saline-soluble, low-molecular-mass lectins (Pemberton, 1994; Rosén, 1996). We recently showed that two such lectins, one (designated $\mathrm{AOL}$ ) isolated from the nematophagous fungus Arthrobotrys oligospora (the anamorphic form of the ascomycete Orbilia auricolor) (Pfister \& Liftik, 1995 ) and the other (ABL) isolated from the mushroom

B Present address: Department of Biology, Texas A \& M University, College Station, TX 77843-3258, USA.

Abbreviations: ABL, Agaricus bisporus lectin; AOL, Arthrobotrys oligospora lectin; $C B B$, Coomassie Brilliant Blue.
Agaricus bisporus, are similar in terms of their primary sequences and binding properties (Rosén et al., 1996a, b; Crenshaw et al., 1995). The sequences of their genes have no significant similarities to the gene sequences of other lectins from micro-organisms, plants or animals thus far sequenced, indicating that they are members of a novel family of lectins found in fungi. More detailed studies of the binding specificities of AOL and ABL have shown them to be multispecific lectins that bind to glycoproteins containing $O$-linked sugar chains (sequence Gal $\beta 3 \mathrm{GalNAc} \alpha$-Ser/Thr), to certain complex $N$ linked sugars, to some sulfated glycoconjugates (e.g. sulfatide) and to the phospholipids phosphatidic acid and phosphatidylglycerol (Rosén et al., 1996b; Presant \& Kornfeld, 1972; Sueyoshi et al., 1985). Although their 
binding specificities are not known in detail, several other fungi contain saline-soluble lectins binding to fetuin and to different mucins, but not to any monosaccharides (Pemberton, 1994; Rosén, 1996). Comparison of the amino acid composition of these lectins, using the method of Cornish-Bowden (1979) as well as data from Southern blots, indicated that several other fungi could also contain lectins related to $\mathrm{AOL}$ and $\mathrm{ABL}$ (Rosén et al., 1996a ; Rosén, 1996).

The biological function(s) of fungal lectins, including $\mathrm{AOL}$ and $\mathrm{ABL}$, has yet to be determined. A. oligospora is a nematode-trapping fungus that can capture and infect nematodes using special hyphae called traps. Based on sugar inhibition experiments, it has been proposed that an $\mathrm{N}$-acetylgalactosamine-specific lectin in A. oligospora mediates the capture of nematodes through binding to a carbohydrate ligand found on the nematode cuticle (Nordbring-Hertz \& Mattiasson, 1979). AOL is similar in size and antigenicity to an apparent $\mathrm{N}$-acetylgalactosamine-specific lectin isolated previously from A. oligospora (Borrebaeck et al., 1984; Rosén et al., 1992). However, the fact that AOL can be very abundant in both trap-containing and vegetative mycelium and the finding that AOL has a primary sequence displaying high similarity to a lectin (ABL) isolated from fruit bodies of a non-parasitic fungus suggest that in fungi these lectins have other more general function(s) not only related to parasitic growth (Rosén et al., 1992, 1996a, b).

In the present study, we investigated the expression and localization of AOL in A. oligospora. The results showed that AOL is a cytoplasmic protein that can function as a storage protein during both saprophytic and parasitic growth.

\section{METHODS}

AOL purification and antibodies. AOL was purified from the mycelium of $A$. oligospora Fres. (ATCC 24927) by affinity chromatography and anion-exchange chromatography (Rosén et al., 1996b). Methods of preparing the monospecific AOL rabbit antibody used in this study and examining its specificity have been reported previously (Rosén et al., 1996a). These antibodies recognize both the major isoform (pI 6.5) and the two minor isoforms (pI 6.3 and 6.1) of AOL (Rosén et al., 1996a). Furthermore, AOL antibodies cross-react with purified ABL (Rosén et al., 1996a).

Expression of lectins in liquid cultures. A. oligospora was grown in a modified low-nutrient mineral salts medium (LNM; Nordbring-Hertz, 1973). The medium contained $\left(\mathrm{l}^{-1}\right)$ : $0.2 \mathrm{~g} \quad \mathrm{MgSO}_{4} .7 \mathrm{H}_{2} \mathrm{O} ; 0.88 \mathrm{mg} \quad \mathrm{ZnSO}_{4} .7 \mathrm{H}_{2} \mathrm{O} ; 0.4 \mathrm{mg}$ $\mathrm{MnSO}_{4} .4 \mathrm{H}_{2} \mathrm{O} ; 3 \mathrm{mg} \mathrm{FeCl} .6 \mathrm{H}_{2} \mathrm{O} ; 1 \mathrm{~g} \mathrm{KCl} ; 25 \mu \mathrm{g}$ biotin; and $200 \mu \mathrm{g}$ thiamin. The medium was supplemented by adding $\left(\mathrm{I}^{-1}\right) 50 \mu \mathrm{g} \quad \mathrm{Na}_{2} \mathrm{MoO}_{4} .2 \mathrm{H}_{2} \mathrm{O}, 3.0 \mathrm{~g} \mathrm{NaH} \mathrm{PO}_{4} . \mathrm{H}_{2} \mathrm{O}, 0.7 \mathrm{~g}$ glucose and either $\mathrm{NH}_{4} \mathrm{HCO}_{3}$ or $\mathrm{NaNO}_{3}$ to produce carbon/ nitrogen $(\mathrm{C} / \mathrm{N})$ ratios of $1,6,30,150$ and 1000 , respectively. The $\mathrm{pH}$ of the medium was adjusted to 6.0 , and the ionic strength (through the addition of $\mathrm{NaCl}$ ) was adjusted to a level corresponding to that of the medium with a $\mathrm{C} / \mathrm{N}$ ratio of 1 . The medium was inoculated with a water suspension of conidia prepared from a culture (2-3 weeks old) of $A$. oligospora grown on corn meal agar (Difco) supplemented with $2 \mathrm{~g} \mathrm{~K}_{2} \mathrm{HPO}_{4} \mathrm{I}^{-1}$. The culture vessels (150 ml medium/ $250 \mathrm{ml}$ Erlenmeyer flasks) were incubated on a rotary shaker (120 r.p.m.) at $20^{\circ} \mathrm{C}$. In another series of experiments, mycelia ( $8 \mathrm{~d}$ old) grown in the medium with a $\mathrm{C} / \mathrm{N}$ ratio of 6 or 150 were filtered and transferred to a new set of vessels containing medium $(150 \mathrm{ml})$ with a $\mathrm{C} / \mathrm{N}$ ratio of 1000 . After incubation $\left(120\right.$ r.p.m., $20^{\circ} \mathrm{C}$ ), the mycelia were repeatedly transferred to new vessels containing the medium with a $C / N$ ratio of 1000 . A last transfer was made to a $\mathrm{C} / \mathrm{N}$ medium $(300 \mathrm{ml})$ with a $\mathrm{C} / \mathrm{N}$ ratio of 6 . During all incubations, the $\mathrm{pH}$ of the medium was between 5.8 and 6.4 , and microscopic inspection revealed that the cultures mainly contained vegetative hyphae, no or only very minor amounts of chlamydospores, and no nematode traps. The cultures were harvested by filtering through paper filters, and the mycelia and filtrates were stored at $-20^{\circ} \mathrm{C}$ prior to further analysis. The total carbon and nitrogen contents of the mycelium were analysed using an elemental analyser (NA 1500; Fisons Instruments). The amount of glucose in the filtrates was analysed as described by Dubois et al. (1956). To obtain trap-containing mycelium in liquid culture, $A$. oligospora was grown in a medium containing $0.01 \%$ (w/v) soya peptone (neutralized; Oxoid) supplemented with $0.05 \mathrm{~g}$ valine and $0.05 \mathrm{~g}$ phenylalanine $\mathrm{l}^{-1}$ (Rosén et al., 1992).

Fruit bodies from a local store were used to obtain a singlespore isolate of $\mathrm{Ag}$. bisporus. Cultures were started from macerated mycelium (cultured on $2 \%$ malt extract agar; Difco) and grown in a defined medium as described by Dons et al. (1979) containing $20 \mathrm{~g}$ glucose and $9 \cdot 2 \mathrm{~g} \mathrm{~L}^{\mathrm{L}}$-asparagine $\mathrm{I}^{-1}$. The $\mathrm{pH}$ was adjusted to 6.0 with $\mathrm{HCl}$. The cultures $(150 \mathrm{ml}$ medium $/ 250 \mathrm{ml}$ Erlenmeyer flasks) were left to grow, without shaking, for $10-20 \mathrm{~d}$ at $20^{\circ} \mathrm{C}$. The lectin content in the fruit bodies of Ag. bisporus (from the store) was also analysed.

Expression of AOL during infection of nematodes. An assay using a dialysis membrane technique was employed (Nordbring-Hertz et al., 1984). Briefly, conidia of A. oligospora were inoculated onto pieces of dialysis membrane and incubated on agar plates (10 g agar no. $1 \mathrm{l}^{-1}$; Oxoid) containing the LNM media. After $3 \mathrm{~d}$ incubation at $20^{\circ} \mathrm{C}$, the formation of nematode traps was induced by adding a few specimens of the nematode Panagrellus redivivus L. (Goodey) to the hyphae growing on the dialysis membranes. After another 7-12 d, by which time all of the nematodes had been captured and degraded by the induced traps (approx. 50-100 traps $\mathrm{cm}^{-2}$ ), the infection experiments were started by adding 20-30 nematodes $\mathrm{cm}^{-2}$. The nematode $P$. redivivus was grown axenically in a soya peptone/liver extract medium (Nordbring-Hertz, 1977).

Immunofluorescence microscopy. Mycelium grown on dialysis membranes was fixed for $2.5 \mathrm{~h}$ in $3 \%(\mathrm{w} / \mathrm{v})$ formaldehyde in PB buffer $(50 \mathrm{mM}$ sodium phosphate buffer, $\mathrm{pH} 6.5$ ) at $20^{\circ} \mathrm{C}$. The membranes were washed in PB buffer and the cell walls of the fungus were permeabilized by treating the mycelium with a buffer containing Novozyme 234 (10 $\mathrm{mg} \mathrm{ml}^{-1}$ in PB buffer; Novo BioLabs) and Lyticase $\left(0.2 \mathrm{mg} \mathrm{ml}^{-1}\right.$; Sigma) for $40-60 \mathrm{~min}$ at $20^{\circ} \mathrm{C}$. The mycelium was washed in PB buffer and blocked with normal goat serum ( $1: 6$ dilution in PB buffer containing $0.2 \%, v / v$, Triton X-100) at $37^{\circ} \mathrm{C}$ for $12 \mathrm{~h}$. The blocked samples were washed in the $\mathrm{PB}$ buffer and incubated with the AOL antibodies $\left(1.3 \mu \mathrm{g} \mathrm{IgG} \mathrm{m}^{-1}\right.$ in PBS containing $0.2 \%$ Triton X-100) for $4 \mathrm{~h}$ at $37^{\circ} \mathrm{C}$, washed in PBS, and subsequently incubated with rhodamineconjugated goat anti-rabbit IgG (1:650 dilution in PBS; Jackson Immunoresearch) for $12-16 \mathrm{~h}$ at $37^{\circ} \mathrm{C}$ (PBS contains 
$4 \mathrm{mM}$ sodium phosphate buffer, $\mathrm{pH} 7 \cdot 2$, and $0 \cdot 15 \mathrm{M} \mathrm{NaCl}$ ). After washing with PBS, the specimens were immersed in $90 \%$ glycerol, $10 \% 50 \mathrm{mM}$ Tris $/ \mathrm{HCl}(\mathrm{pH} 8 \cdot 7)$, containing $0.1 \% n$ propyl gallate and observed with a Nikon Diaphot-300 microscope equipped with an epifluorescence system.

Immunoelectron microscopy. Mycelia from liquid cultures or dialysis membranes were soaked with fixation solution (50 mM sodium phosphate buffer, $\mathrm{pH} \mathrm{7.2,} \mathrm{containing} 2.5 \%$, $\mathrm{w} / \mathrm{v}$, paraformaldehyde and $0.5 \%, \mathrm{w} / \mathrm{v}$, glutaraldehyde). Subsequently, samples were selected and fixation was continued at $0{ }^{\circ} \mathrm{C}$ for $3 \mathrm{~h}$. The samples were washed in the phosphate buffer, dehydrated in a graded ethanol series, and finally embedded in Unicryl (British Biocell International). Grids carrying ultrathin sections of the samples were preadsorbed on drops of $0.5 \%(\mathrm{w} / \mathrm{v}) \mathrm{BSA}$ and $20 \mathrm{mM}$ glycine in PBS for $20 \mathrm{~min}$ at room temperature. The blocked grids were incubated for $16 \mathrm{~h}$ at $4{ }^{\circ} \mathrm{C}$ in $\mathrm{AOL}$ antibody solution $(0.3 \mu \mathrm{g}$ IgG ml $\mathrm{m}^{-1}$ in the PBS buffer containing glycine and BSA) and washed four times in PBS with $20 \mathrm{mM}$ glycine. The grids were incubated for $1 \mathrm{~h}$ at room temperature with $15 \mathrm{~nm}$ colloidal gold-conjugated, goat anti-rabbit IgG (diluted 30 times in the BSA/glycine-containing buffer) (Amersham). They were then washed three times in the PBS/glycine buffer and distilled water, post-stained with uranyl acetate $(1 \%, \mathrm{w} / \mathrm{v}$, in water $)$ for $10 \mathrm{~s}$, and examined in a transmission electron microscope (Philips, CM 10).

To check whether the affinity of the AOL antibodies was affected by the fixation procedure, dot blots of AOL were treated with the fixation buffer or the phosphate buffer only for $3 \mathrm{~h}$ at $0{ }^{\circ} \mathrm{C}$. The membranes were washed in the same buffer, incubated with the AOL antibodies and then treated as described below.

Protein analyses. Liquid-grown mycelium $(40-45 \mathrm{mg}$ wet wt, corresponding to $8-9 \mathrm{mg}$ dry $\mathrm{wt}$ ), fruit bodies or mycelium recovered from the dialysis membranes (from approx. $10 \mathrm{~cm}^{-2}$ ) was extracted to recover saline-soluble proteins by sonication $\left(2 \times 30 \mathrm{~s}\right.$ at $0^{\circ} \mathrm{C}$ using a Bransonic 4210 model sonicator) in $0.75 \mathrm{ml}$ PBS. After centrifugation, the protein content of each supernatant was determined according to the method described by Bradford (1976) or using a fluorometric assay (NanoOrange; Molecular Probes) with BSA as standard. SDS-PAGE was performed using a MiniProtean II electrophoresis cell (Bio-Rad). Gels were stained with Coomassie Brilliant Blue (CBB). The molecular mass was indicated by using a Bio-Rad prestained SDS-PAGE standard kit including BSA $(97.2 \mathrm{kDa})$, ovalbumin $(50 \mathrm{kDa})$, carbonic anhydrase $(35.1 \mathrm{kDa})$, soybean trypsin inhibitor $(29.7 \mathrm{kDa})$ and lysozyme $(21.9 \mathrm{kDa})$. The haemagglutinating activity of the extracts was measured as described previously (Rosén et al., 1992), and the amount of AOL or ABL was determined using an ELISA. Extracts were serially diluted in microtitre wells, dotted onto nitrocellulose membranes and incubated with the AOL antibodies. Amounts of $\mathrm{AOL}$ and $\mathrm{ABL}$ were estimated according to standard procedures using a secondary antibody (alkaline-phosphatase-conjugated goat anti-rabbit antibody) (Harlow \& Lane, 1988).

Northern and slot blots. RNA was isolated from the mycelia by acid guanidinium thiocyanate/phenol/chloroform extraction (Chomczynski \& Sacchi, 1987). RNA from liquid-grown mycelia was separated by denaturing formaldehyde agarose $(1 \%, \mathrm{w} / \mathrm{v})$ electrophoresis (Sambrook et al., 1989) and transferred to a Hybond- $\mathrm{N}^{+}$membrane (Amersham). The filters were hybridized with a ${ }^{32} \mathrm{P}$-labelled cDNA probe of AOL (a HindIII-XbaI insert of pAOL11; see Rosén et al., 1996a) using the random prime labelling method (Rediprime;
Amersham). Filters were washed at $65^{\circ} \mathrm{C}$ in $6 \times$ SSC and $0 \cdot 1 \%(\mathrm{w} / \mathrm{v})$ SDS before being autoradiographed $(1 \times$ SSC contains $0 \cdot 15 \mathrm{M} \mathrm{NaCl}$ and $0 \cdot 015 \mathrm{M}$ sodium citrate, $\mathrm{pH} 7 \cdot 0$ ). As a loading control, the Northern blot filters were hybridized with a DNA probe specific for $18 \mathrm{~S} \mathrm{rDNA}$ obtained from Vicia faba (Yakura et al., 1984).

RNA extracted from the mycelia grown on the dialysis membranes was analysed using a slot blot apparatus (Milliblot; Millipore). The amount of applied RNA was approximately $50 \mathrm{ng}$ as determined by a fluorometric assay (SYBRII Green; Molecular Probes) (Schmidt \& Ernst, 1995). Filters (Hybond-N; Amersham) were hybridized with the cDNA probe of AOL and examined using a Storm 840 Phosphor image analyser (Molecular Dynamics).

Labelling of surface proteins. Proteins present on the surface of trap-containing mycelium of A. oligospora were labelled with ${ }^{125} \mathrm{I}$ using a water-soluble Bolton-Hunter reagent (Pierce). About $200 \mu \mathrm{l}$ of a mycelium suspension (grown for 7 d) was labelled with $1 \mathrm{mCi}\left(3.7 \times 10^{7} \mathrm{~Bq}\right) \mathrm{Na}^{125} \mathrm{I}$ at $0{ }^{\circ} \mathrm{C}$ as described by Thompson et al. (1987). The labelled mycelium was washed with PBS, transferred to an Eppendorf tube, $150 \mu \mathrm{l}$ PBS was added, and the labelled mycelium was disrupted by sonication $\left(3 \times 30 \mathrm{~s}\right.$ at $0^{\circ} \mathrm{C}$ using a Bransonic 4210 model sonicator). To further facilitate disruption of the cells, glass beads (diameter $0.5 \mathrm{~mm}$ ) were added to some of the samples prior to sonication. The specific activity obtained was estimated to be $4-5 \times 10^{8}$ c.p.m. ( $\mu$ g protein) $)^{-1}$. Furthermore, ${ }^{125}$ I-labelling did not appear to affect the binding properties and specificities of AOL as revealed by comparing the binding properties of biotinylated and ${ }^{125}$ I-labelled AOL and the effects of various inhibitors on the haemagglutinating activity of radiolabelled and unlabelled AOL (S. Rosén \& A. Tunlid, unpublished data). Extracts were cleared by centrifugation $\left(10000 \mathrm{~g}, 10 \mathrm{~min}, 4^{\circ} \mathrm{C}\right)$ and analysed by gel chromatography using a Superose 6 column (Pharmacia) with a flow rate of $0.4 \mathrm{ml} \mathrm{min}^{-1}$ (PBS). Fractions were collected every minute; radioactivity was quantified using a gamma counter and $\mathrm{AOL}$ was detected using ELISA (see above) and SDS-PAGE. For comparison, mycelium disrupted by sonication before the labelling reagents were added was also analysed by gel chromatography. To bind any AOL that was present in the labelled extracts, the extract was incubated for $2 \mathrm{~h}$ in an Eppendorf tube with an affinity gel immobilized with porcine stomach mucin (Rosén et al., 1992). The samples were centrifuged, and the affinity gel was washed with PBS. The supernatant (unbound proteins) and the gel were boiled for $5 \mathrm{~min}$ in SDS-PAGE sample buffer and analysed by SDSPAGE. To detect ${ }^{125}$ I-labelled proteins, the dried gels were exposed to X-ray films (Rosén et al., 1996b).

\section{RESULTS}

\section{Production of $A O L$ in liquid cultures}

Neither AOL nor its transcript were detected in the fungal mycelium grown for 2-3 $\mathrm{d}$ in any of the media tested (Fig. 1). Subsequently, the level of the AOL transcript and the amount of the protein were dependent on the $\mathrm{C} / \mathrm{N}$ ratios of the medium. The highest levels of $\mathrm{AOL}$ and the corresponding mRNA were found in mycelia growing in the medium with the lowest $\mathrm{C} / \mathrm{N}$ ratios (1 or 6) tested. After 5-11 d growth in these media, by which time the fungus had entered the stationary growth phase, it was estimated that AOL comprised approximately $5-20 \%$ of the total amount of 
(a)

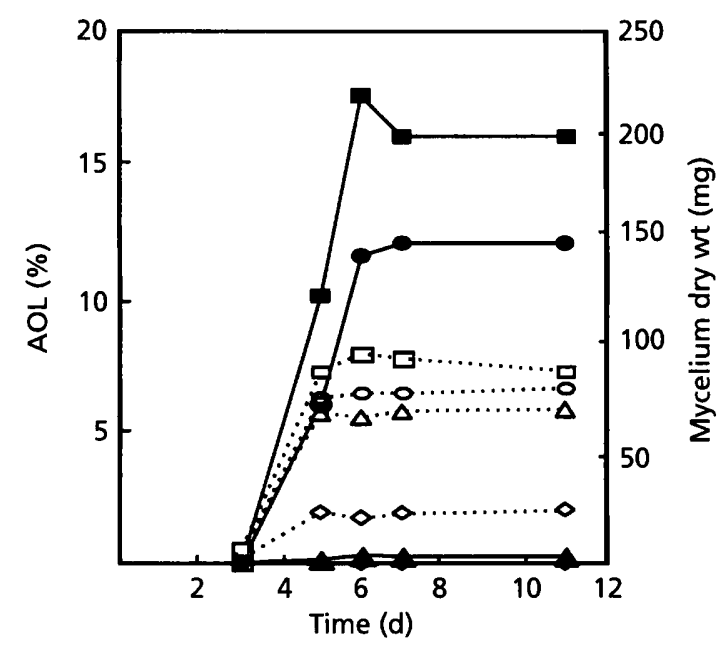

Fig. 1. Expression of AOL mRNA and the corresponding protein in $A$. oligospora during growth in liquid media of various $C / N$ ratios using glucose as the carbon (C) source and ammonia as the nitrogen (N) source. (a) AOL content (expressed as percentage of the total amount of saline-soluble proteins) (filled symbols and solid lines), and the dry weight of the mycelium (open symbols and dotted lines). $\square, \square, C / N=1 ; 0$, $0, C / N=6 ; \Delta, \triangle, C / N=30 ; \diamond, \diamond, C / N=150$. Data are means of three parallel experiments. (b) Northern blots of total RNA extracted from the mycelia. Filters were hybridized with a ${ }^{32} \mathrm{P}$ labelled CDNA probe of AOL and with a DNA probe specific for 185 rDNA (loading control). The experiments were repeated twice with similar results.

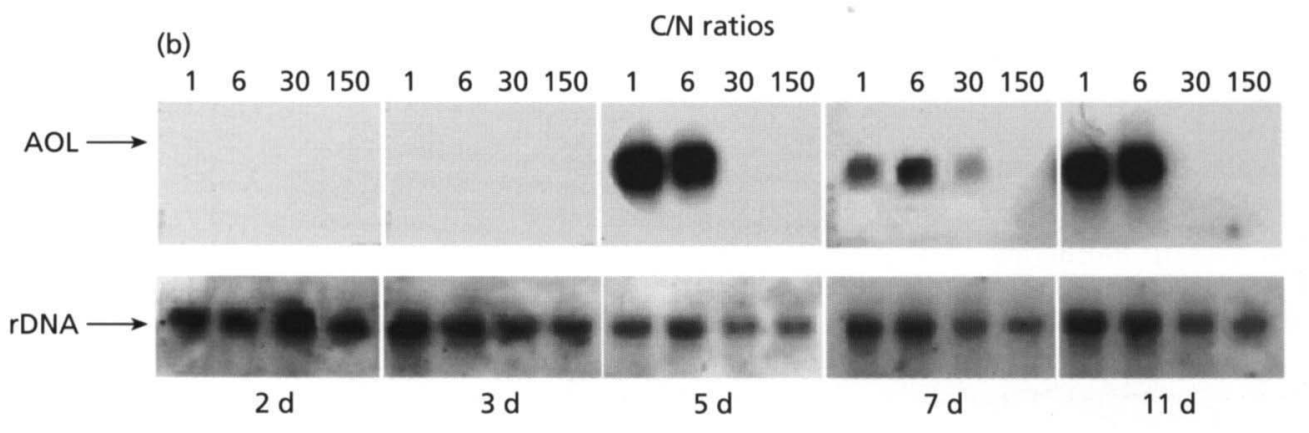

saline-soluble proteins in the mycelium. In the mycelium grown at a $\mathrm{C} / \mathrm{N}$ ratio of 30 , the content of $\mathrm{AOL}$ was $<1 \%$, whereas in the medium with a $\mathrm{C} / \mathrm{N}$ ratio of 150 it was not possible to detect the lectin or the corresponding transcript. Similar results were obtained in the cultures, irrespective of whether the nitrogen source was $\mathrm{NH}_{4}^{+}$or $\mathrm{NO}_{3}^{-}$. In all samples, patterns of change were similar for the level of the AOL transcript, the AOL amount, and haemagglutinating activity (data not shown). Extracellular AOL in low amounts ( $<10 \mathrm{ng} \mathrm{ml}^{-1}$, corresponding to $<1 \%$ of the total amount of AOL extracted from the mycelium) was also detected in the filtrates of cultures growing at the lowest $\mathrm{C} / \mathrm{N}$ ratios (1 and 6) for 10-11 d.

\section{Degradation of $A O L$ during starvation}

The level of AOL in A. oligospora decreased rapidly when mycelia containing large amounts of AOL (grown in medium with a $\mathrm{C} / \mathrm{N}$ ratio of 6 ) were repeatedly transferred (four times, numbered I-IV) to a medium with a $\mathrm{C} / \mathrm{N}$ ratio of 1000 (Fig. 2a). Between transfers I and II, the AOL content (\%) of the total amount of saline-soluble proteins decreased 7.1-fold ( $\mathrm{SD}=3 \cdot 5, n=$ 4), and it continued to decrease during subsequent transfers, reaching non-detectable levels after transfer III. Total amounts of AOL in the mycelium at transfers $\mathrm{I}$ and II were $0.45 \mathrm{mg}(\mathrm{SD}=0.26, n=4)$ and $0.098 \mathrm{mg}$
$(\mathrm{SD}=0 \cdot 10, n=4)$, respectively. In contrast, the total amount of soluble proteins in the mycelium did not start to decrease until the time after transfer III (Fig. 2a). Concomitant with the decrease in protein content, the nitrogen content of the mycelium decreased. At the time for transfer I, the mycelium contained $3.8 \%$ nitrogen $(\mathrm{C} / \mathrm{N}$ ratio $=11 \cdot 2)$, and at transfer IV, the mycelium contained $1.8 \%$ nitrogen $(\mathrm{C} / \mathrm{N}$ ratio $=27 \cdot 4)$. That the relative amount of AOL compared with other salinesoluble proteins in the mycelium decreased after the transfers was also evident from SDS-PAGE analysis of proteins extracted from the mycelium (Fig. $2 b$ ).

Mycelial growth and the level of the carbon source (glucose) in the media were also followed during the starvation experiments (Fig. 2c). The mycelial biomass increased significantly after the first transfer. The biomass at transfers I and II was $90 \mathrm{mg}(\mathrm{sD}=5 \cdot 4, n=$ 5) and $127 \mathrm{mg}(\mathrm{SD}=7 \cdot 8, n=4)$, respectively. Later transfers resulted in a gradually lower increase in the biomass of the mycelium compared with that occurring during the initial transfers. No sugars were detected in the media after transfers I and II. However, after transfer III, at the time when no AOL was detected in the mycelium, the filtrates of the culture media contained detectable levels of glucose, indicating that some factor other than carbon limited the growth of the fungus (Fig. 2c). To check whether growth was limited by the volume of medium, mycelium at transfer IV was grown 
(b)

(a)

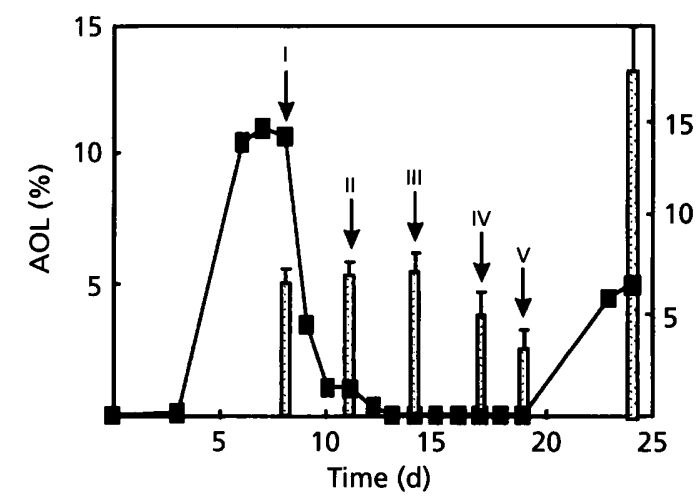

(c)

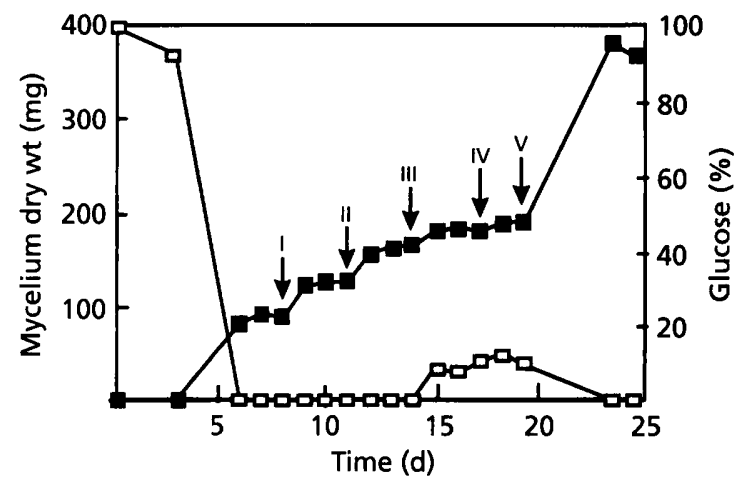

$\mathrm{kDa}$

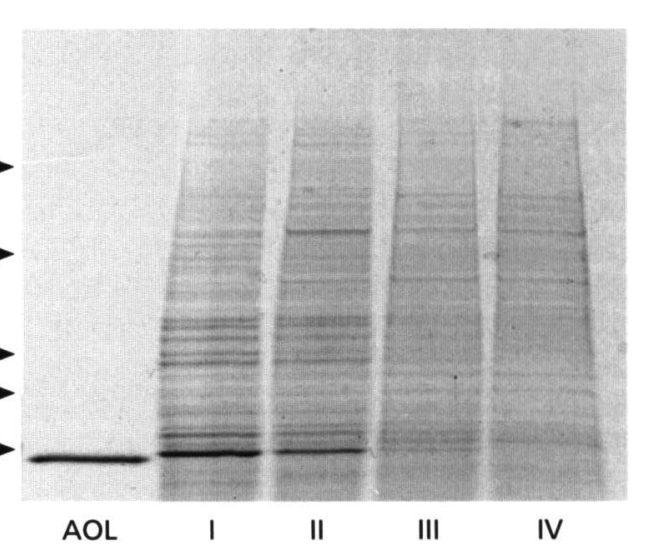

(d)

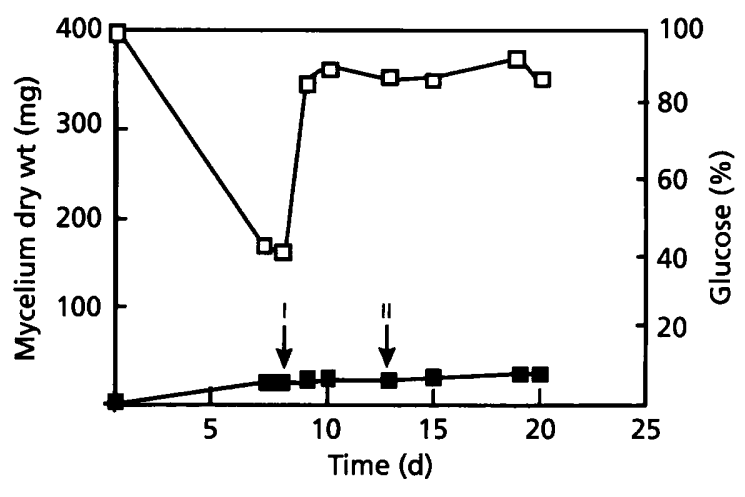

Fig. 2. Degradation of $A O L$ during starvation. Mycelia of $A$. oligospora grown for $8 \mathrm{~d}$ in a medium with a $C / N$ ratio of 6 (see Fig. 1) were transferred four times (indicated by numbers I-IV) to new vessels containing medium with a C/N ratio of 1000 (volume $150 \mathrm{ml}$ ) and thereafter to medium with a $\mathrm{C} / \mathrm{N}$ ratio of 6 (transfer $\mathrm{V}$; volume $300 \mathrm{ml}$ ). Arrows indicate the times for transfers I-V. The experiments were repeated four times with similar results. (a) $\square, A O L$ content, expressed as percentage of the total amount of saline-soluble proteins in the mycelium. Columns, total amount (mean) of salinesoluble proteins present in the mycelium (bars show SD with $n=4$ ). (b) SDS-PAGE (stained with CBB) of AOL (1.4 $\mu \mathrm{g})$ and saline-soluble proteins extracted from the mycelium at the time of transfers I-IV; $5 \mu \mathrm{g}$ protein was loaded on the gels. (c) Dry weight $(\boldsymbol{\square})$ of the transferred mycelia and the level of glucose $(\square)$ in the culture filtrate (expressed as the percentage of the total level of sugars present in the fresh media). (d) Dry weight ( $\square$ ) and level of glucose ( $\square$ ) in the culture filtrate when transferring mycelia containing no $A O L$ (grown for $8 \mathrm{~d}$ in a medium with a $\mathrm{C} / \mathrm{N}$ ratio of 150; see Fig. 1) to new vessels containing medium with a $\mathrm{C} / \mathrm{N}$ ratio of 1000 .

in either 150 or $300 \mathrm{ml}$ medium. There was no significant difference in the biomass of the mycelium growing in the two volumes.

To determine whether the repeatedly transferred mycelium still had the capacity to respond to an added nitrogen source, a final transfer $(\mathrm{V})$ was made to a medium with a $\mathrm{C} / \mathrm{N}$ ratio of 6 . A significant increase in biomass as well as in AOL content was observed after this transfer (Fig. 2a, c). The growth response of mycelium of $A$. oligospora containing no AOL (grown in a medium with a $\mathrm{C} / \mathrm{N}$ ratio of 150 ) was also examined during the course of repeated transfers to medium with a $\mathrm{C} / \mathrm{N}$ ratio of 1000 (Fig. $2 \mathrm{~d}$ ). This mycelium did not show an increase in biomass similar to that of the mycelium transferred from the $\mathrm{C} / \mathrm{N} 6$ medium, and a major proportion of the glucose present in the media was not utilized during the incubation (Fig. 2d). The nitrogen content of the mycelium grown for $10 \mathrm{~d}$ (between transfers I and II) was $1.4 \%(\mathrm{C} / \mathrm{N}$ ratio $=$ $36 \cdot 6)$.

\section{Localization of $A O L$ in vegetative mycelium}

Immunoelectron microscopy showed AOL to be abundantly present in the cytoplasm and the nucleus of the vegetative mycelium grown for $5-11 \mathrm{~d}$ in media with low $\mathrm{C} / \mathrm{N}$ (1 or 6) ratios (Fig. 3a). Little or no labelling was found on the fungal cell walls. Almost no labelling was detected in samples of young mycelia $(<4 \mathrm{~d})$ (Fig. $3 \mathrm{~b}$ ) or in mycelia grown in medium with a $\mathrm{C} / \mathrm{N}$ ratio of 150 (not shown). Control samples treated with the preimmune antibodies and secondary antibodies or with 

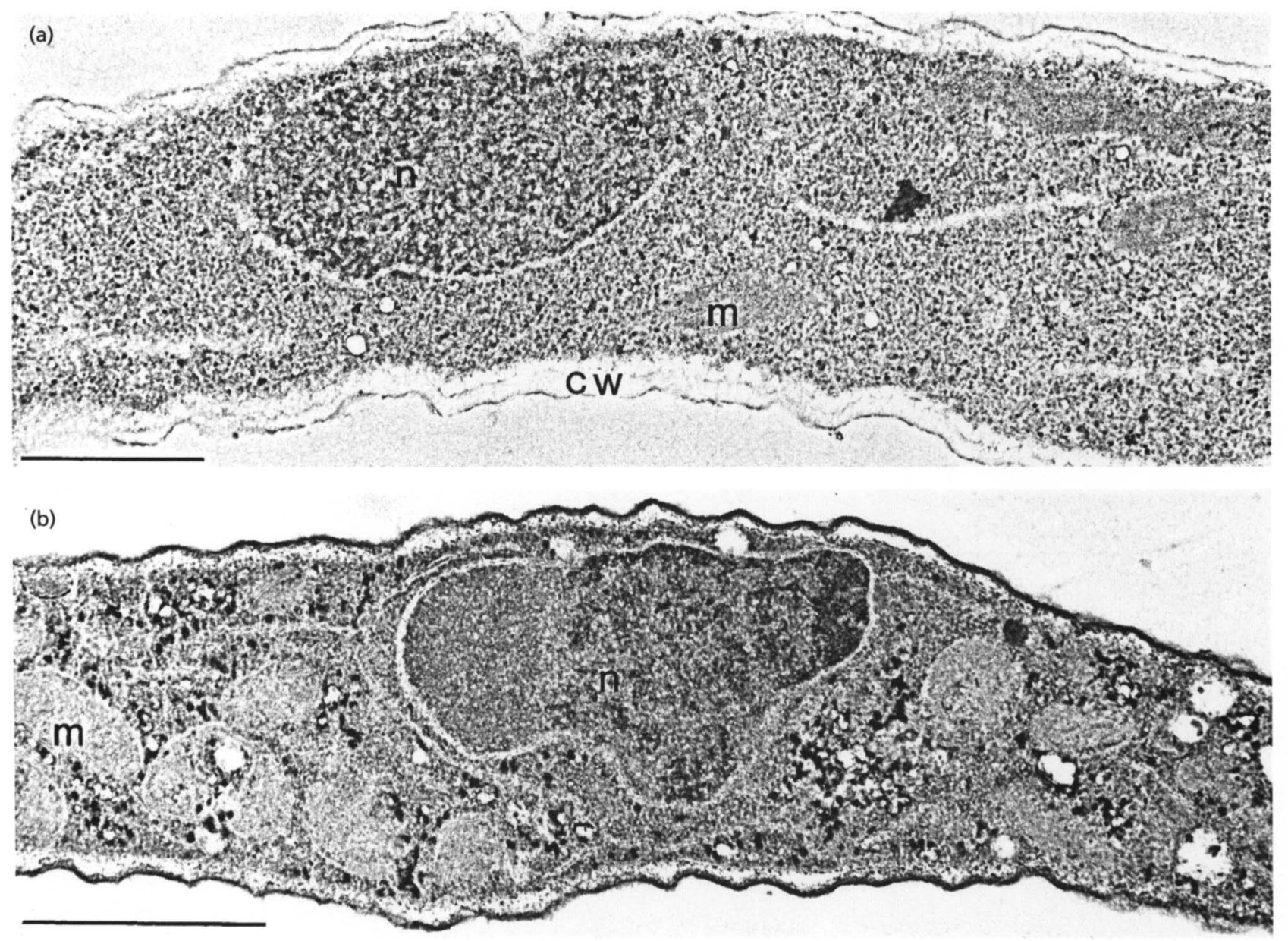

Fig. 3. Immunolocalization of $A O L$ in vegetative mycelium of $A$. oligospora. The fungus was grown in a liquid medium with a C/N ratio of 6 for 3 or $6 \mathrm{~d}$ (see Fig. 1). Ultrathin sections were stained with AOL antibodies, whereupon the grids were treated with goat anti-rabbit IgG-colloidal gold ( $15 \mathrm{~nm}$ particle size) and examined by electron microscopy. (a) Sample of mycelium grown for $6 \mathrm{~d}$. The antibodies labelled the cytoplasm and the nucleus, but no labelling was observed in other organelles or in the cell wall. (b) Sample of mycelium grown for $3 \mathrm{~d}$. Little or no labelling was found in the cytoplasm or nucleus. cw, Cell wall; $m$, mitochondria; $n$, nucleus. Bars, $1 \mu \mathrm{m}$.

secondary antibodies only did not show any labelling. Furthermore, incubating dot blots of AOL with the electron microscopy fixation buffer did not affect the antigenicity of the protein.

\section{Analysis of surface-labelled $\left({ }^{125}\right)$ proteins of $A$. oligospora}

No ${ }^{125}$ I-labelled AOL was detected when proteins extracted from the labelled mycelium were analysed by gel chromatography (Fig. 4a). In contrast, AOL was one of the major radiolabelled proteins in the extract where the mycelium had been disrupted before the labelling reagent had been added. This demonstrates that it was possible to label AOL using the present method, but that the protein was mainly present intracellularly (Fig. 4a). A protein extract from the labelled mycelium was also incubated with a porcine stomach mucin affinity gel to bind AOL. SDS-PAGE followed by exposure to X-ray film showed that only trace levels of the bound $\mathrm{AOL}$ were labelled with ${ }^{125}$ I (Fig. 4b, c; lane 1).

\section{Expression of $\mathrm{AOL}$ during the infection of nematodes}

Only low levels of AOL mRNA were detected in $A$. oligospora during the induction of trap cells and during the first $2 \mathrm{~d}$ of the infection of the nematode $P$. redivivus. However, after 3-5 d infection, high levels of the transcript as well as the corresponding protein were detected (Fig. 5a, b). The level of AOL increased from $0.13 \% \quad(\mathrm{SD}=0 \cdot 04, n=3)$ at the start of infection to a maximum value (days $3-5)$ of $3.0 \%(\mathrm{sD}=1 \cdot 9, n=3)$ (expressed as percentage of the total amount of salinesoluble proteins).

Examination of the infection process using immunofluorescence microscopy confirmed that the fungus contained very low levels of AOL during the trapinduction phase and early stages of infection. Some trap 


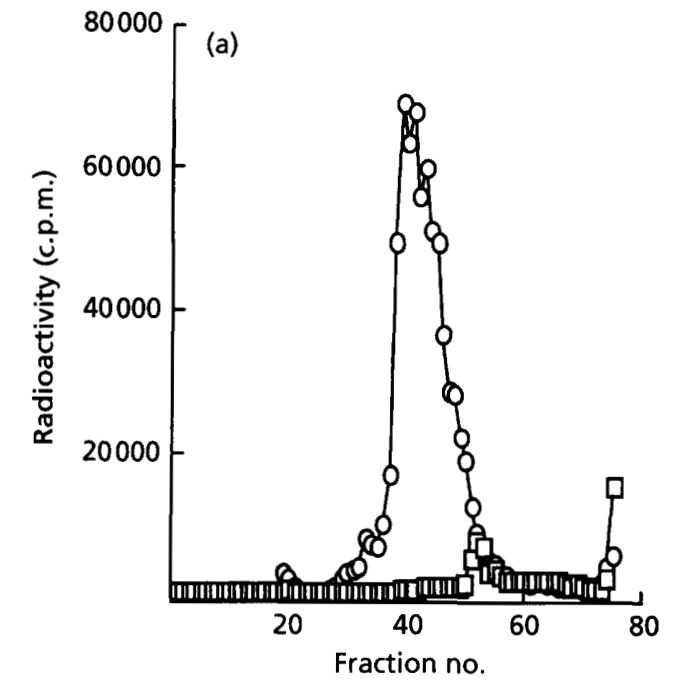

(b)

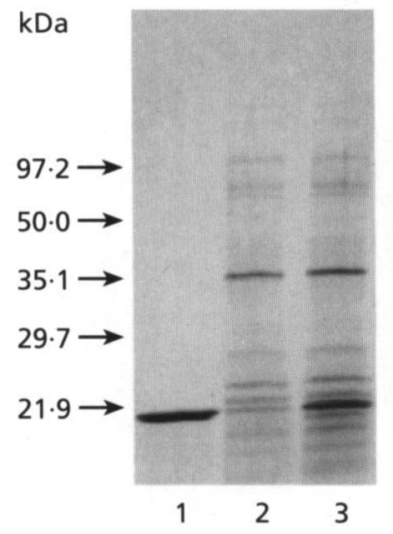

(c)

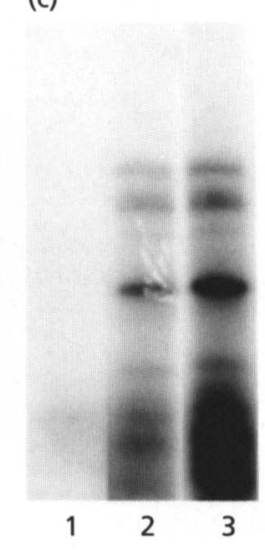

(a)

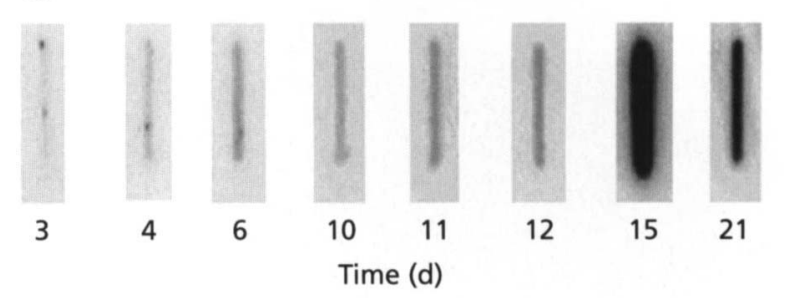

(b)
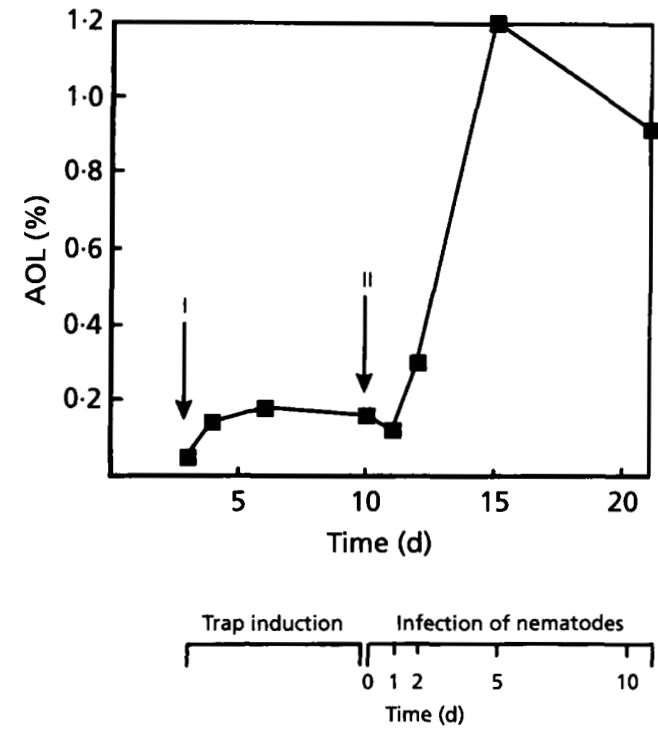

Fig. 5. Expression of AOL mRNA and the corresponding protein in $A$. oligospora during infection of the nematode $P$. redivivus. The fungus was grown on dialysis membranes for $3 d$, whereupon nematodes were added to induce trap formation (arrow l). After another 7-12 d incubation, the infection experiments were started by adding nematodes to the trapcontaining mycelium (arrow II). After various times of infection, membranes were collected, and RNA and saline-soluble proteins were extracted. (a) Slot blots of total RNA hybridized with a ${ }^{32}$ p-labelled CDNA probe of AOL. Approximately $50 \mathrm{ng}$ RNA was applied to each lane. (b) Level of AOL (ELISA) expressed as percentage of the total amount of saline-soluble proteins. Experiments were repeated three times with similar results.

(5-10 d after adding nematodes), AOL was mainly detected in trap cells (Fig. 6i, $\mathrm{j}$ ).

\section{Ultrastructural localization of AOL during the infection of nematodes}

As indicated by immunofluorescence microscopy, electron microscopy showed that some trap cells contained AOL, whereas others did not (Fig. 7a, b). The localization of AOL in the trap cells was similar to that observed in the vegetative mycelium, with abundant labelling observed in the cytoplasm and nucleus (Fig. $7 a)$. During the capture of nematodes, no labelling was detected in the cell wall or in the layer of extracellular polymers present between the traps and the nematode cuticle. In the trophic hyphae growing inside the infected 

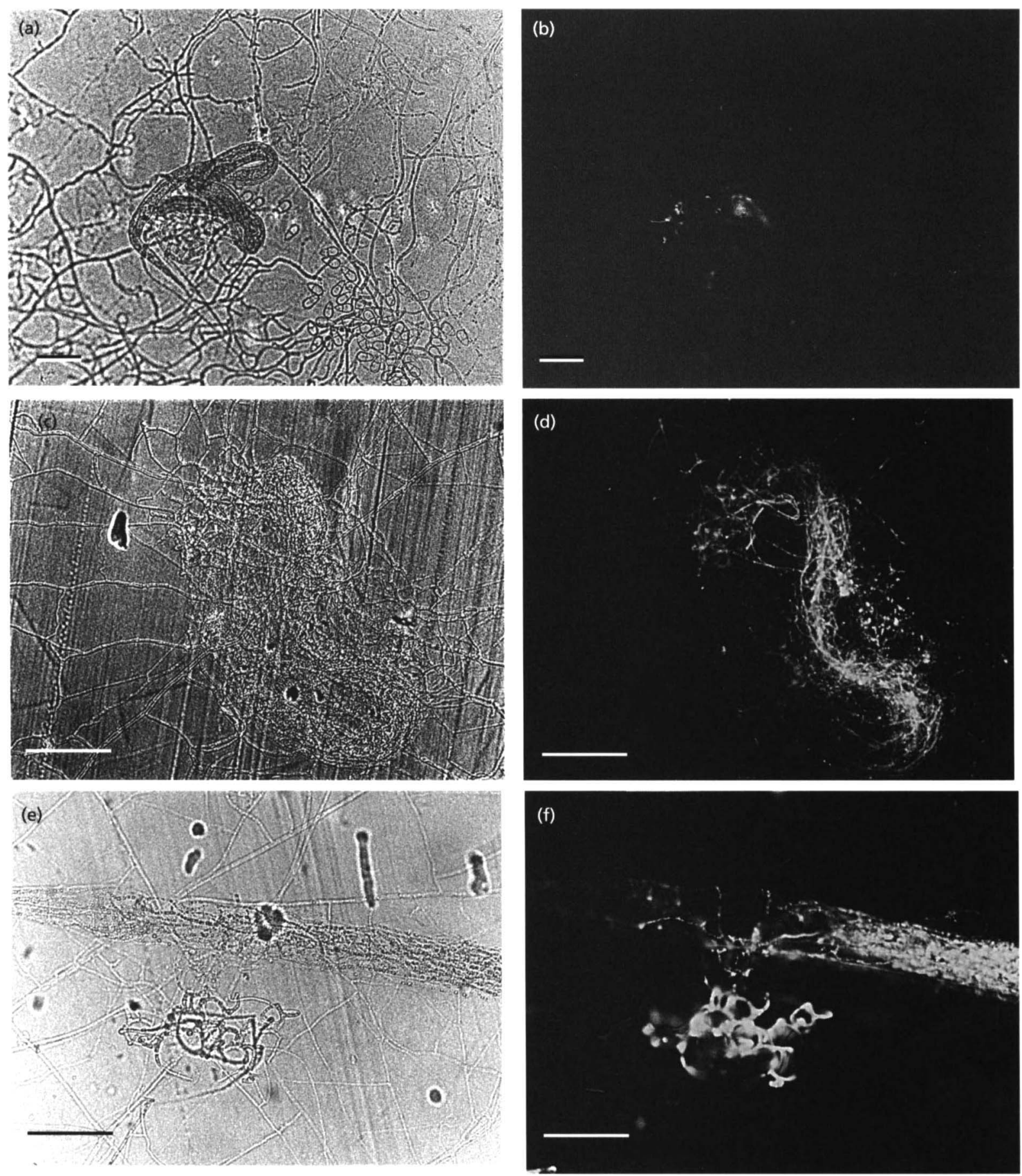

Fig. 6. For legend see facing page.

nematodes, extensive labelling of AOL was detected in the cytoplasm and nucleus (Fig. 7c). At this time, large lipid droplets were clearly visible in the fungal cells.

\section{Expression of ABL in Ag. bisporus}

Western blots of protein extracts from vegetative mycelium and fruit bodies of Ag. bisporus using the
AOL antibodies showed that these antibodies recognized ABL with high specificity. The mycelium analysed had been grown for 10-20 d in liquid cultures using medium with a $\mathrm{C} / \mathrm{N}$ ratio of 7 . In the mycelium, the mean level of ABL, as revealed by ELISA, was $18.7 \%$ of the total amount of soluble proteins ( $\mathrm{SD}=10 \cdot 7, n=3$ ). The mean level of ABL in fruit bodies was $0.22 \%(\mathrm{sD}=$ $0 \cdot 13, n=4$ ). 

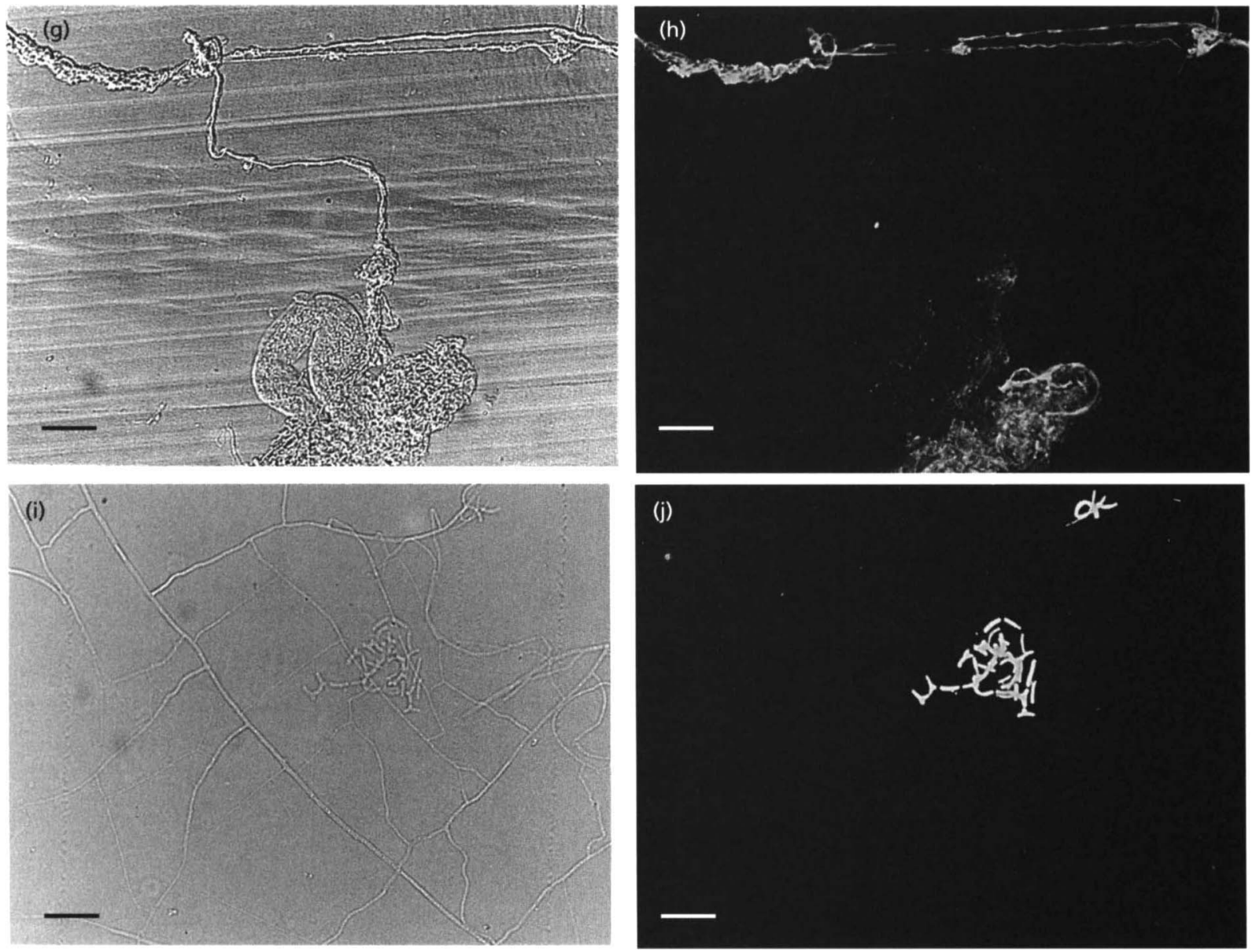

Fig. 6. Immunofluorescence microscopy of $A O L$ in $A$. oligospora during the infection of nematodes. The infection process (see Fig. 5) was followed by light (left-hand side) and immunofluorescence (right-hand side) microscopy using antibodies specific for AOL. ( $a, b)$ Two hours after adding nematodes (arrow II on day 10 in Fig. 5). Nematodes adhered to the trap cells. No or low levels of AOL were detected mainly localized to areas of mycelium where the nematodes added initially for inducing the trap cells had been captured and digested by the fungus. It appeared that both traps staining for AOL and those not staining could capture nematodes. (c, d) Two and a half days after adding nematodes (day 12 in Fig. 5). infected nematodes have been penetrated and their internal tissues almost completely digested. There is intensive intracellular fluorescent staining of $\mathrm{AOL}$ in hyphae growing inside the nematode. Vegetative mycelium growing just outside the nematode is also stained. (e, $f$ ) Two and a half days after adding nematodes (day 12). Newly developed trap cells with intensive fluorescent staining have formed outside the degraded nematode. $(g, h)$ Five days after adding nematodes (day 15). There is staining of $A O L$ in aggregates of vegetative hyphae (mycelial strand) extending from a region containing both a digested and more recently captured nematode. ( $i, j)$ Ten days after adding nematodes (day 20 ). The lectin was mainly found localized to trap cells (intracellular). Bars, $50 \mu \mathrm{m}$.

\section{DISCUSSION}

Several results presented in this paper support the idea that a lectin (AOL) present in the nematophagous fungus A. oligospora functions as a storage protein during both saprophytic and parasitic growth: (1) the expression of AOL is metabolically and developmentally regulated; (2) the lectin can accumulate in large amounts in the mycelium when growing in a medium with a high nitrogen content (low $\mathrm{C} / \mathrm{N}$ ratios) or when infecting a nematode; (3) under conditions of nitrogen starvation, AOL is degraded to a higher degree compared with other proteins. It has also been shown that the plantpathogenic soil fungus Rhizoctonia solani tends to accumulate high levels of a developmentally regulated, saline-soluble lectin (RSL) during growth in nitrogenrich medium (Kellens \& Peumans, 1990). Although the primary sequence of RSL has not been reported, the amino acid compositions of RSL and AOL appear to be related (Rosén, 1996). Few details are available concerning the patterns of expression of saline-soluble lectins in other fungi. However, the finding that $A B L$, whose primary sequence and binding properties are similar to those of AOL (Rosén et al., 1996a, b), could be strongly expressed in the vegetative mycelium of the saprophyte Ag. bisporus indicates that this lectin can also function as a storage protein.

The increase in the expression of the AOL gene in $A$. oligospora during later stages of the infection of the 

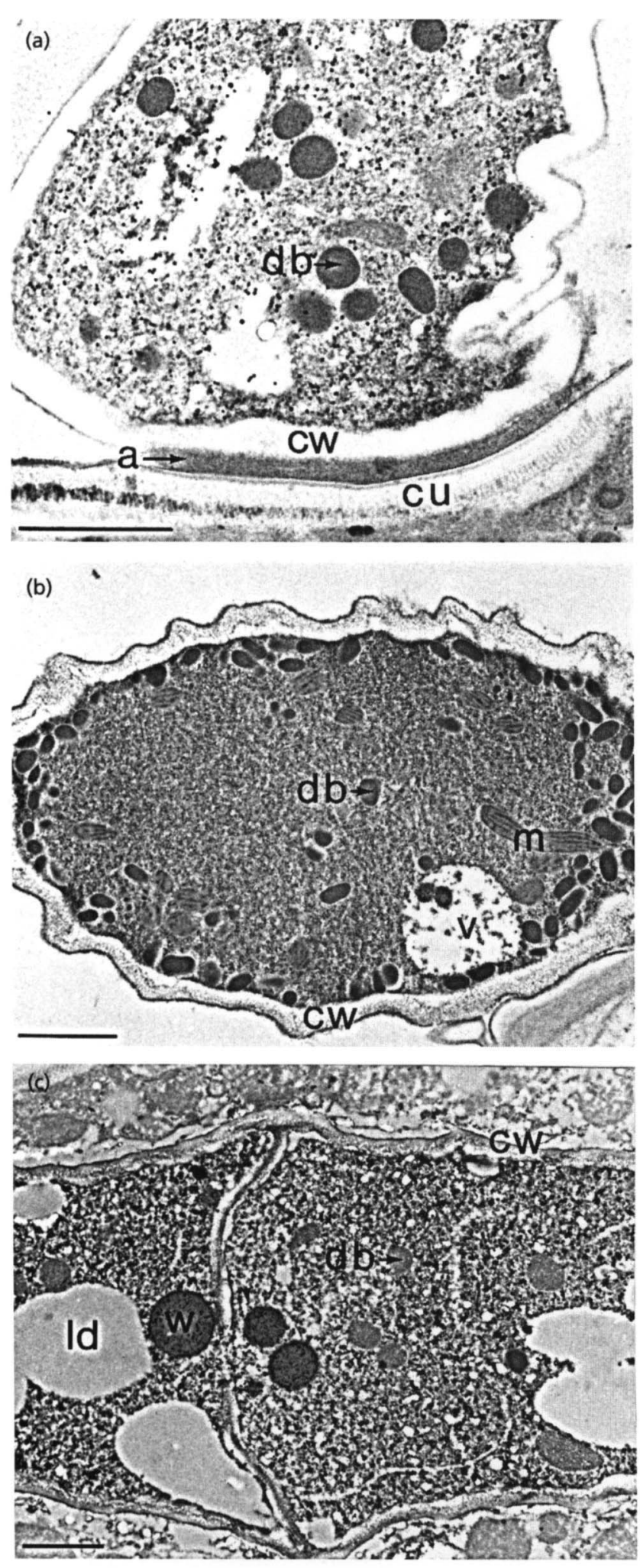

Fig. 7. Immunolocalization of $\mathrm{AOL}$ in $A$. oligospora during infection of nematodes using electron microscopy. The fungus was grown on pieces of dialysis membrane, as described in Fig. 5 , and the samples were prepared as presented in the legend to Fig. 3. (a) Adhesion of a nematode to the traps of the fungus (approx. 1-2 $\mathrm{h}$ after the nematodes were added). The cytoplasm and the nucleus of the fungus were labelled. Occasionally, nematode $P$. redivivus occurred in parallel with an extensive expression of $\mathrm{AOL}$ in the trophic hyphae growing inside the infected nematodes. In these hyphae, lipid droplets were clearly visible. Other studies have indicated that lipid droplets which develop in the trophic hyphae are involved in the assimilation and storage of nutrients obtained from the captured nematodes (Veenhuis et al., 1989a). Furthermore, the extensive and stable fluorescent staining of AOL observed in the traps growing outside the infected nematodes indicates that AOL was preferentially accumulated and stored in the infection structures. Previous work has shown that the network traps of $A$. oligospora can survive longer than normal hyphae, which suggests that the traps may function as survival structures (Veenhuis et al., 1985, $1989 b)$. Notably, we also observed that AOL was preferentially found in aggregates of parallel hyphae. Such mycelial strands have not been described previously in $A$. oligospora, but are common among soil ascomycetes and basidiomycetes (Moore, 1995). It is possible that the mycelial strands formed by $A$. oligospora are used to translocate nitrogen, in the form of AOL, from the site of a digested nematode to other areas of the mycelium growing in more favourable microhabitats or supporting the development of fruit bodies or conidiophores, in a similar way to mycelial strands translocating nitrogen in saprophytic fungi (Moore, 1995; Watkinson, 1984). The degradation of AOL under starvation conditions in the liquid cultures occurred in parallel with an increase in the biomass of the mycelium, which indicates that nitrogen stored in the lectin was used to support growth of the fungus.

Based on biochemical analyses of various cell fractions, we previously reported that AOL is an abundant extracellular protein associated with surface polymers of A. oligospora (Rosén et al., 1992). Data from immunoelectron microscopy suggest that these results were an artifact caused by cell lysis occurring during the extraction of the mycelium. However, since trace levels of AOL were detected extracellularly, both in the cell wall of the mycelium labelled with the Bolton-Hunter reagent and in the medium of the liquid-grown mycelium, we cannot exclude the possibility that under certain growth conditions AOL can be secreted. The localization of AOL to the cytoplasm is in agreement with the observation that the deduced primary structure of AOL lacks a typical N-terminal signal sequence (Rosén et al., 1996a). Several animal lectins have been localized to the cytoplasm and nucleus, including the galectins, a family of $\beta$-galactoside lectins found in animals (Barondes et al., 1994). Notably, a fungal

traces of AOL labelling were detected inside the nematode body at the site of penetration. (b) Trap cell without any labelling of AOL. (c) Trophic hyphae growing inside the infected nematode (approx. $2 \mathrm{~d}$ after the nematodes were added). There is intense labelling of the cytoplasm. a, Layer of adhesive polymers; $\mathrm{cw}$, cell wall; $\mathrm{db}$, dense bodies; Id, lipid droplet; $m$, mitochondria; v, vacuole; $w$, Woronin body; $c u$, nematode cuticle. Bars, $1 \mu \mathrm{m}$. 
galectin was recently detected in the mushroom Coprinus cinereus, but the primary sequence of this lectin is not related to that of AOL and ABL (Cooper et al., 1997).

Although the results presented in this paper show that AOL serves as a storage protein, they cannot explain the function of the binding specificities of the lectin. In vitro binding studies have shown that $\mathrm{AOL}$ and $\mathrm{ABL}$ are multispecific lectins which bind to sugar chains that are common in animal glycoproteins, but not found in fungi (Kobata, 1992; Herscovics \& Orlean, 1993; Rosén et al., 1996b). One possibility is that AOL interacts with sugar ligands present on the nematode surface, thereby contributing to the capture of nematodes according to mechanisms suggested by Nordbring-Hertz \& Mattiasson (1979). However, since AOL was not detected in the surface polymer layer on the trap cells, traps without a detectable fluorescent signal for AOL captured nematodes, and nematode capture was not inhibited by treating the traps with different ligands of AOL or by treating the nematodes with purified AOL (Rosén, 1996), it seems unlikely that AOL was involved in mediating adhesion to the nematodes according to the previously suggested model. AOL and similar lectins in fungi might also be components of a system of defence against various animal fungivores. Such a function has been suggested for a number of intracellular plant lectins (Peumans \& Van Damme, 1995). Furthermore, most of these plant lectins appear to function as storage proteins.

\section{ACKNOWLEDGEMENTS}

This study was supported by grants from the Banks of Sweden Tercentenary Foundation, the Swedish Natural Science Research Council, Crafoordska Stiftelsen, and Kungliga Fysiografiska Sällskapet in Lund. We thank Professor Birgit Nordbring-Hertz and Dr Stefan Olsson for stimulating discussions.

\section{REFERENCES}

Barondes, S. H., Cooper, D. N. W., Gitt, M. A. \& Leffler, H. (1994). Galectins. Structure and function of a large family of animal lectins. J Biol Chem 269, 20807-20810.

Borrebaeck, C. A. K., Mattiasson, B. \& Nordbring-Hertz, B. (1984). Isolation and partial characterization of a carbohydrate binding protein from a nematode-trapping fungus. J Bacteriol 159, 53-56.

Bradford, M. M. (1976). A rapid and sensitive method for the quantitation of microgram quantities of protein utilizing the principle of protein-dye binding. Anal Biochem 72, 248-254.

Chomczynski, P. \& Sacchi, N. (1987). Single-step method of RNA isolation by acid guanidinium thiocyanate-phenol-chloroform extraction. Anal Biochem 162, 156-159.

Cooper, D. N. W., Boulianne, R. P., Charlton, S., Farrell, E. M., Sucher, A. \& Lu, B. C. (1997). Fungal galectins, sequence and specificity of two isoforms from Coprinus cinereus. J Biol Chem 272, 1514-1521.

Cornish-Bowden, A. (1979). How reliably do amino acid comparisons predict sequence similarities between proteins? J Theor Biol 76, 369-386.

Crenshaw, R. W., Harper, S. N., Moyer, M. \& Privalle, L. S. (1995).
Isolation and characterization of a cDNA clone encoding a lectin gene from Agaricus bisporus. Plant Physiol 107, 1465-1466.

Dons, J. J. M., de Vries, O. M. H. \& Wessels, J. G. H. (1979). Characterization of the genome of the basidiomycete Schizophyllum commune. Biochim Biophys Acta 563, 100-112.

Dubois, M., Gilles, K. A., Hamilton, J. K., Rebers, P. A. \& Smith, F. (1956). Colorimetric method for determination of sugars and related substances. Anal Chem 28, 350-356.

Harlow, E. \& Lane, D. (1988). Antibodies: a Laboratory Manual. Cold Spring Harbor, NY: Cold Spring Harbor Laboratory.

Herscovics, A. \& Orlean, P. (1993). Glycoprotein biosynthesis in yeast. FASEB J 7, 540-550.

Kellens, J. T. C. \& Peumans, W. J. (1990). Developmental accumulation of lectin in Rhizoctonia solani: a potential role as a storage protein. J Gen Microbiol 136, 2489-2495.

Kobata, A. (1992). Structures and functions of the sugar chains of glycoproteins. Eur J Biochem 209, 483-501.

Moore, D. (1995). Tissue formation. In The Growing Fungus, pp. 423-465. Edited by N. A. R. Gow \& G. M. Gadd. London: Chapman \& Hall.

Nordbring-Hertz, B. (1973). Peptide-induced morphogenesis in the nematode-trapping fungus Arthrobotrys oligospora. Physiol Plant 29, 223-233.

Nordbring-Hertz, B. (1977). Nematode induced morphogenesis in the predacious fungus Arthrobotrys oligospora. Nematologica 23, 443-451.

Nordbring-Hertz, B. \& Mattiasson, B. (1979). Action of a nematode-trapping fungus shows lectin-mediated host-microorganism interaction. Nature 281, 477-479.

Nordbring-Hertz, B., Veenhuis, M. \& Harder, W. (1984). Dialysis membrane technique for ultrastructural studies of microbial interactions. Appl Environ Microbiol 45, 290-293.

Pemberton, R. T. (1994). Agglutinins (lectins) from some British higher fungi. Mycol Res 98, 277-290.

Peumans, W. J. \& Van Damme, E. J. M. (1995). Lectins as plant defense proteins. Plant Physiol 109, 347-352.

Pfister, D. H. \& Liftik, M. E. (1995). Two Arthrobotrys anamorphs from Orbilia auricolor. Mycologia 87, 684-688.

Presant, C. A. \& Kornfeld, S. (1972). Characterization of the cell surface receptor for the Agaricus bisporus hemagglutinin. J Biol Chem 247, 6937-6945.

Rosén, S. (1996). Fungal lectins. Molecular structure and function of a member of a novel lectin family. PhD thesis, Lund University.

Rosén, S., Ek, B., Rask, L. \& Tunlid, A. (1992). Purification and characterization of a surface lectin from the nematode-trapping fungus Arthrobotrys oligospora. J Gen Microbiol 138, 2663-2672.

Rosén, S., Kata, M., Persson, Y., Lipniunas, P. H., Wikström, M., van den Hondel, C. A. M. J. J., van den Brink, J. M., Rask, L., Hedén, L.-O. \& Tunlid, A. (1996a). Molecular characterization of a saline soluble lectin from a parasitic fungus. Extensive sequence similarities between fungal lectins. Eur J Biochem 238, 822-829.

Rosén, S., Bergström, J., Karlsson, K.-A. \& Tunlid, A. (1996b). A multispecific saline soluble lectin from the parasitic fungus Arthrobotrys oligospora. Similar binding specificities as a lectin from the mushroom Agaricus bisporus. Eur $J$ Biochem 238, 830-837.

Sambrook, J., Fritsch, E. F. \& Maniatis, T. (1989). Molecular Cloning: a Laboratory Manual, 2nd edn. Cold Spring Harbor, NY: Cold Spring Harbor Laboratory.

Schmidt, D. M. \& Ernst, J. D. (1995). A fluorometric assay for the 
quantification of RNA in solution with nanogram sensitivity. Anal Biochem 232, 144-146.

Sueyoshi, S., Tsuji, T. \& Osawa, T. (1985). Purification and characterization of four isolectins of mushroom (Agaricus bisporus). Biol Chem Hoppe-Seyler 366, 213-221.

Thompson, J. A., Lau, A. L. \& Cunningham, D. D. (1987). Selective radiolabeling of cell surface proteins to a high specific activity. Biochemistry 26, 743-750.

Veenhuis, M., Nordbring-Hertz, B. \& Harder, W. (1985). Development and fate of electron-dense microbodies in trap cells of the nematophagous fungus Arthrobotrys oligospora. Antonie Leeuwenboek 51, 399-407.

Veenhuis, M., Harder, W. \& Nordbring-Hertz, B. (1989a). Occurrence and metabolic significance of microbodies in trophic hyphae of the nematophagous fungus Arthrobotrys oligospora. Antonie Leeuwenboek 56, 241-249.
Veenhuis, M., Van Wijk, C., Wyss, U., Nordbring-Hertz, B. \& Harder, W. (1989b). Significance of electron dense microbodies in trap cells of the nematophagous fungus Artbrobotrys oligospora. Antonie Leeuwenhoek 56, 251-261.

Watkinson, S. C. (1984). Morphogenesis of the Serpula Lacrimans colony in relation to its function in nature. In The Ecology and Physiology of the Fungal Mycelium, pp. 165-184. Edited by D. H. Jennings \& A. D. M. Rayner. Cambridge: Cambridge University Press.

Yakura, K., Kato, A. \& Tanifuji, S. (1984). Length heterogeneity of the large spacer of Vicia faba rDNA is due to the differing number of a 325 bp repetitive sequence elements. Mol Gen Genet 193, $400-405$.

Received 4 March 1997; revised 25 April 1997; accepted 30 April 1997. 